\title{
Pengaruh Sumber Informasi dan Dukungan Kelembagaan terhadap Kemandirian Petani di Provinsi Sumatera Selatan
}

\section{Effect of Information Sources and Institutional Support to Independence of Farmers in Province of South Sumatera}

\author{
Ali Alamsyah Kusumadinata ${ }^{1, *}$, Sumardjo ${ }^{2}$, Dwi Sadono ${ }^{2}$, Burhanuddin $^{3}$
}

\author{
${ }^{1}$ Program Studi Ilmu Komunikasi, Universitas Djuanda Bogor, Bogor 16720, Indonesia \\ ${ }^{2}$ Departemen Sains Komunikasi dan Pengembangan Masyarakat, IPB Bogor, Bogor 16680, Indonesia \\ ${ }^{3}$ Departemen Agribisnis, Fakultas Ekonomi dan Manajemen, IPB Bogor, Bogor 16680 Indonesia \\ ${ }^{*}$ E-mail korespondensi: ali.kusumadinata@yahoo.com
}

Diterima: 19 Agustus 2020 | Disetujui: 14 April 2021 | Publikasi Online: 22 April 2021

\begin{abstract}
The weak independence of farmers in managing farming is characterized by weak levels of farmer production and selling prices that are still determined by market conditions. The information sources owned by farmers are not strong enough to help farmers in analyzing problems faced by farmers ranging from land preparation, cultivation, harvesting to post-harvest. Therefore, the study aimed to look at the influence of agricultural information sources on the support of the institutional environment of farmers on the independence of farmers. This research used a quantitative approach with survey methods in Ogan Ilir Districts and Banyuasin Districts, South Sumatera Province. This study used a sample of 294 farmers who joined farmer groups. This research showed that the weak source of information used by farmers and the low support of the institutional environment results in the farmers' independence being quite weak. Farmers have not been able to build competitiveness, filter and partnership in the scope of their lives up to farmer groups. The independent model of farmers was able to explain $91 \%$ of sources of information and institutional environment support. Therefore, it was necessary to strengthen accurate, correct, in-depth information and adapt it to local site conditions.
\end{abstract}

Keywords: Independence of farmers, information support, institutional source

\begin{abstract}
ABSTRAK
Lemahnya kemandirian petani dalam mengelola usahatani ditandai dengan lemahnya tingkat produksi petani dan harga jual yang terdominasi oleh pelaku hilir agribisnis. Sumber informasi yang diakses petani tidak membantu petani dalam menganalisa permasalahan yang dihadapi petani mulai dari persiapan lahan, budidaya, panen hingga pascapanen. Oleh karena itu penelitian ini bertujuan melihat pengaruh sumber informasi pertanian terhadap dukungan lingkungan kelembagaan petani terhadap kemandirian petani. Penelitian ini menggunakan pendekatan kuantitatif dengan metode survei di Kabupaten Ogan Ilir dan Kabupaten Banyuasin, Provinsi Sumatera Selatan. Penelitian ini menggunakan sampel sebanyak 294 petani yang bergabung dalam kelompok tani. Penelitian ini menunjukkan bahwa ternyata lemah sumber informasi yang digunakan oleh petani, demikian juga dukungan lingkungan kelembagaan pertanian, telah mengakibatkan lemahnya kemandirian petani. Petani belum mampu membangun daya saing, daya saring dan daya sanding dalam lingkup kelompok tani. Model kemandirian petani mampu menjelaskan sebesar $91 \%$ terhadap sumber informasi dan dukungan lingkungan kelembagaan. Hal ini bermakna adanya kebutuhan penguatan informasi yang akurat, benar, dan mendalam serta disesuaikan dengan kondisi lokasi setempat.
\end{abstract}

Kata Kunci: Kemandirian petani, sumber informasi, dukungan kelembagaan

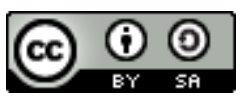

Content from this work may be used under the terms of the Creative Commons Attribution-ShareAlike

4.0 International. Any further distribution of this work must maintain attribution to the author(s) and the title of the work, journal citation and DOI.

Published under Department of Communication and Community Development Science, IPB University and in association with Perhimpunan Ahli Penyuluhan Pembangunan Indonesia.

E-ISSN: 2442-4110 | P-ISSN: 1858-2664 


\section{PENDAHULUAN}

Besarnya jumlah petani padi yang mengusahakan pangan memerlukan suatu kemampuan dan kompetensi dalam menangani usahatani yang dikelola. Hal ini tidak sejalan dengan kondisi di lapangan yang sering mengalami masalah. Kemandirian petani masih lemah sehingga memungkin petani dapat mengalami kerugian dalam usahatani. Kabupaten Banyuasin dan Kabupaten Ogan Ilir, Provinsi Sumatera Selatan merupakan bagian dari wilayah yang menjadi lumbung pangan masyarakat Provinsi Sumatera Selatan. Kemandirian petani yang dimiliki masih sangat lemah (Malta et al. 2018). Sumardjo (2019) mengartikan kemandirian sebagai suatu daya yang mampu memberikan dorongan pada petani untuk memberikan pertimbangan, menganalisa dan mengambil keputusan serta membangun jaringan. Daya tersebut terdiri dari daya saing, saring dan sanding. Kemandirian petani semacam ini pada penelitian terdahulu menunjukkan berkorelasi positif dengan tingkat kesejahteraan petani. Managanta et al. (2019) menyatakan bahwa kemandirian pada petani rendah disebabkan oleh dukungan dari lembaga yang rendah utamanya pada aspek pemasaran, pemodalan, pengolahan dan bimbingan teknis.

Deressa et al. (2009) dan Cai et al. (2008) menyatakan bahwa kemandirian sulit terwujud karena infrastruktur yang kurang baik, biaya transportasi yang tinggi, kualitas produk yang rendah, akses informasi yang kurang memadai dan pemodalan yang rendah hingga menyebabkan daya tawar ke petani rendah. Selain itu, fasilitas informasi yang rendah terhadap pengelolaan budidaya pertanian dan pemasarannya (Shahbaz et al. 2010). Anantanyu et al. (2009) menyatakan bahwa petani di pedesaan mampu mengembangkan sosial ekonomi petani, ketersediaan informasi pertanian, modal, infrastruktur dan pasar dengan membentuk kelembagaan petani. Pemerintah dan swasta dituntut untuk mampu memberikan penguatan fasilitas dan kebijakan kepada petani. Managanta et al. (2018) menyimpulkan bahwa peningkatan kemandirian petani dapat dilakukan dengan meningkatkan kemampuan teknis dalam produksi sesuai dengan standar kerja, mampu menjalin kerjasama dengan industri, swasta, pemodal dan lembaga penyuluh serta mengembangkan kelompok tani dalam aspek pemasaran, pemodalan, pengolahan dan bimbingan teknis.

Indraningsih (2011) menyatakan penyuluhan yang intensif mampu meningkatkan keyakinan petani terhadap informasi yang diperoleh petani. Perilaku komunikasi petani yang dicirikan dari kerja sama, kekosmopolitan dan keterdedahan media meingkatkan kemampuan petani dalam aspek pengembangan usahatani yang dikelola. Komunikasi interpersonal penyuluh di lapangan membuka ruang petani untuk mendalami konsep teknologi yang digunakan sebagai bagian yang akan diadopsi. Marquart et al. (1995) menemukan bahwa kedekatan petani secara interpersonal antar petani inovasi dan penyuluh mampu memberikan kredibilitas lebih terhadap informasi teknologi pangan yang diusahakan. Sesungguhnya, Van den Ban dan Hawkins (1999), menyatakan bahwa peran penyuluh sebagai sumber informasi dan lembaga pertanian menekankan pada perubahan perilaku bertani secara efektif dan efisien hingga mampu meningkatkan pendapatan petani.

Sunartomo (2016) mengungkapkan bahwa kemampuan penyuluh yang terbatas mampu dikelola dengan membangun jaringan komunikasi antar petani dalam kelompok tani sehingga dapat mengisi kekosongan informasi yang dimiliki petani. Keterbatasan penyuluh dibangun pendidikan penyuluhan melalui kelompok tani yang terbuka terhadap inovasi dari petani. Penyuluhan pertanian merupakan bagian sistem pendidikan nonformal petani yang dekat dengan petani dan mampu mengkonfirmasi informasi sehingga perilaku dan kapasitas petani lebih baik dari sebelumnya.

Mittal dan Mehar (2013) mengungkapkan bahwa sumber informasi petani terdiri atas pertemuan langsung secara tatap muka, petani dan petani, media tradisional serta media informasi dan teknologi komunikasi baik menggunakan daring maupun luring. Informasi yang didapat petani akan dikonfirmasi kembali oleh petani melalui lembaga pertanian yang dekat dengan petani khususnya kelompok tani dan rekan petani.

Suhaeti et al. (2015) dan Prawiranegara et al. (2016) mengungkapkan bahwa kemampuan petani dalam mengolah produk menjadi barang siap jual masih terkendala dengan modal dan informasi serta dukungan dari kelembagaan. Arus informasi penting dalam kemandirian, informasi merupakan hal yang mutlak dimiliki oleh petani, terutama dukungan lembaga dalam memberikan pengarahan dalam menghadapai ketidakpastian dan kompleksitas informasi, pasar dan perubahan iklim yang cepat. Malta et al. (2018) mengemukakan dalam penelitian di Provinsi Sumatera Selatan bahwa keberdayaan petani yang rendah disebabkan oleh ketersediaan faktor pendukung (sarana usaha, informasi, modal usaha, 
transportasi, pasar dan kelayakan lahan) serta dukungan lingkungan sosial budaya berupa tokoh masyarakat dan keberadaan kelompok. Malta et al. (2018) juga mengusulkan bahwa perlunya: (1) peningkatan ketersediaan daya dukung; (2) menumbuhkembangkan koperasi desa; (3) inovasi pertanian; (4) penyelesaian konflik antar petani dan perusahaan; (5) pelibatan tokoh masyarakat serta (6) pengembangan kegiatan penyuluh. Penelitian terdahulu memfokuskan pada aspek kemandirian, sumber informasi dan dukungan kelembagaan yang terpisah, namun pada penelitian ini, peneliti membangun peubah sumber informasi dan dukungan lingkungan kelembagaan yang merupakan faktor yang mempengaruhi kemandirian petani secara bersama. Atas pertimbangan ini, penelitian ini bertujuan untuk mendeskripsikan sumber informasi dan dukungan lingkungan kelembagaan serta menganalisis pengaruh antar kedua peubah bebas tersebut terhadap kemandirian petani.

\section{METODE PENELITIAN}

Penelitian ini dilakukan di Provinsi Sumatera Selatan, tepatnya di Kabupaten Ogan Ilir dan Kabupaten Banyuasin. Penelitian ini melibatkan 294 petani yang bergabung dengan kelompok tani. Penelitian dilakukan pada Januari - Mei 2019. Pengambilan sampel secara multi stage random sampling mulai dari provinsi, kabupaten hingga desa secara terpilih dengan mempertimbangkan banyaknya jumlah kelompok tani di wilayah tersebut. Prosedur penggunaan multi stage random sampling digunakan dengan mempertimbangkan jumlah sampel yang terwakilkan dalam wilayah yang tersebar luas dan memiliki tingkatan jenjang populasi yang berbeda. Tujuan penggunaan multi stage random sampling untuk mewakili setiap jenjang wilayah yang diambil sebagai sampel penelitian. Sampel diambil dari data Kabupaten Banyuasin dan Kabupaten Ogan Ilir yang diturunkan ke masing-masing kecamatan dan diambil sampel kelompok tani yang berada di desa dengan melihat keberagaman tingkatan kelompok yang bersumber dari data Simluhtan tahun 2019 dan konfirmasi dari kantor Balai Penyuluh Pertanian (BPP) setempat. Data yang diambil melalui kuesioner dan observasi di lapangan. Analisis pengolahan data dilakukan dengan tabulasi serta analisis pengaruh menggunakan partial least squares regression (PLS) dengan persamaan kemandirian petani $=\gamma 1$ sumber infomasi $+\gamma 2$ dukungan lingkungan kelembagaan. Dimana hipotesis yang digunakan adalah terdapat pengaruh sumber informasi dan dukungan lingkungan kelembagaan terhadap kemandirian petani. Peubah penelitian dijelaskan pada Tabel 1.

Tabel 1. Peubah penelitian

\begin{tabular}{|c|c|c|c|}
\hline Peubah & Definisi & Indikator & Skala Ukuran \\
\hline $\begin{array}{l}\text { Sumber Informasi } \\
\text { (X1) }\end{array}$ & $\begin{array}{l}\text { Institusi atau personal } \\
\text { yang memiliki }\end{array}$ & $\begin{array}{l}\text { 1. Media non- } \\
\text { konvensional }\end{array}$ & $\begin{array}{l}\text { Rendah:0-50, } \\
\text { Sedang:51-75, }\end{array}$ \\
\hline Peubah Bebas & $\begin{array}{l}\text { kemampuan dalam } \\
\text { memberikan informasi } \\
\text { berkenaan usahatani } \\
\text { padi. }\end{array}$ & $\begin{array}{l}\text { 2. Media konvensional } \\
\text { 3. Kelompok tani } \\
\text { 4. Lembaga inovasi } \\
\text { 5. Petani inovator }\end{array}$ & Tinggi:76-100 \\
\hline $\begin{array}{l}\text { Dukungan Lingkungan } \\
\text { Kelembagaan (X2) }\end{array}$ & $\begin{array}{l}\text { Institusi yang mampu } \\
\text { memberikan }\end{array}$ & $\begin{array}{l}\text { 1. Dukungan kebijakan } \\
\text { 2. Bumdes }\end{array}$ & $\begin{array}{l}\text { Rendah:0-50, } \\
\text { Sedang:51-75, }\end{array}$ \\
\hline Peubah Bebas & $\begin{array}{l}\text { pemberdayaan kepada } \\
\text { masyarakat secara } \\
\text { langsung dan tidak } \\
\text { langsung. }\end{array}$ & $\begin{array}{l}\text { 3. Perusahaan pertanian } \\
\text { 4. Dukungan penyuluh } \\
\text { 5. Dukungan pemasaran } \\
\text { 6. Dukungan infrastruktur }\end{array}$ & Tinggi:76-100 \\
\hline $\begin{array}{l}\text { Kemandirian } \\
\text { (Y1) }\end{array}$ & $\begin{array}{l}\text { Kemampuan petani } \\
\text { dalam mengembangkan } \\
\text { diri agar kebih berdaya } \\
\text { dan mampu } \\
\text { meningkatkan kualitas } \\
\text { diri dan jaringan usaha } \\
\text { pertanian. }\end{array}$ & $\begin{array}{l}\text { 1. Daya saing } \\
\text { 2. Daya saring } \\
\text { 3. Daya sanding }\end{array}$ & $\begin{array}{l}\text { Rendah:0-50, } \\
\text { Sedang:51-75, } \\
\text { Tinggi:76-100 }\end{array}$ \\
\hline
\end{tabular}

Penelitian ini dilanjutkan dengan menganalisis data dengan deskriptif frekuensi dengan membandingkan dua kabupaten dan menguji dengan uji beda menggunakan t-test pada taraf $5 \%$. Selanjutnya dilanjutkan dengan menguji hipotesis (1) terdapat pengaruh sumber informasi pertanian 
terhadap kemandirian petani, dan (2) terdapat pengaruh dukungan lingkungan kelembagaan terhadap kemandirian petani. Selanjutnya dianalisis dengan menggunakan persamaan kemandirian petani. Analisis pengaruh menggunakan Program SmartPLS 3.2.9. Gambar 1 merupakan kerangka pemikiran penelitian ini.

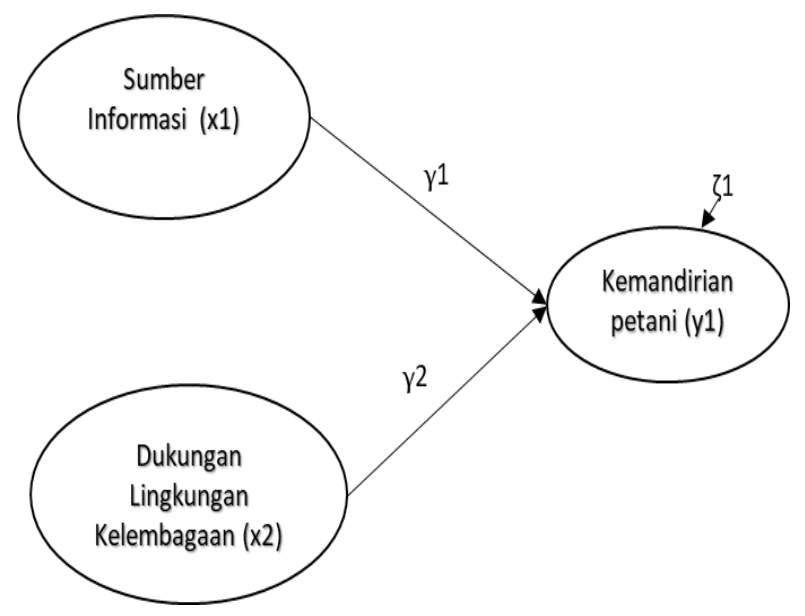

Gambar 1. Kerangka berpikir penelitian.

\section{HASIL DAN PEMBAHASAN}

\section{Sumber Informasi Pertanian}

Sumber informasi pertanian terdiri dari media nonkonvensional, media konvensional, kelompok tani, lembaga inovasi (perguruan tinggi (PT), Balai Penyuluh Pertanian (BPP), Balai Pengkajian Teknologi Pertanian (BPTP), Balai Besar Padi) dan petani inovator. Lima media informasi ini memberikan informasi kepada petani berkenaan dengan usahatani yang dikelola. Pengelolaan informasi dilakukan oleh petani langsung dan membicarakan kepada keluarga inti hingga mengambil keputusan terhadap usahatani yang digeluti. Hal-hal yang menjadi pembicaraan adalah pratanam, pembudidayaan, pemeliharaan, pemanenan, pemasaran. Sumber informasi yang dimanfaatkan oleh petani adalah melalui kelompok tani dan petani inovator. Kelompok tani yang merupakan bagian dari petani dan memiliki peran dalam membantu petani dalam memberikan pertimbangan informasi. Petani inovator merupakan bagian dari petani setempat atau di luar desa yang memiliki nilai produksi yang baik, dengan pengamatan terhadap petani inovator ini, petani lain mampu memberikan pertimbangan petani untuk meniru atau mengadopsi pola pertanian yang digunakan. Gambaran Rata-rata tingkat sumber informasi pertanian terdapat pada Tabel 2.

Tabel 2. Rata-rata tingkat sumber informasi pertanian di Kabupaten Ogan Ilir dan Kabupaten Banyuasin Provinsi Sumatera Selatan, 2019

\begin{tabular}{|c|c|c|c|c|}
\hline \multirow[b]{2}{*}{$\begin{array}{c}\text { Tingkat Sumber Informasi } \\
\text { Pertanian }\end{array}$} & \multicolumn{3}{|c|}{ Rata-rata } & \multirow[b]{2}{*}{$\begin{array}{c}\text { Uji Beda (t-Test) } \\
\text { Singnifikan (2-Tailed) } \\
\text { p }<0,05\end{array}$} \\
\hline & $\begin{array}{c}\text { Kab. } \\
\text { Banyuasin } \\
\mathbf{n = 2 1 9}\end{array}$ & $\begin{array}{l}\text { Kab. Ogan Ilir } \\
n=75\end{array}$ & $\begin{array}{c}\text { Total } \\
\mathrm{n}=294\end{array}$ & \\
\hline Media Nonkonvensional & 44 & 48 & 45 & $0,000 * *$ \\
\hline Media Konvensional & 46 & 45 & 46 & 0,151 \\
\hline Kelompok Tani & 66 & 71 & 67 & $0,000 * *$ \\
\hline Lembaga Inovasi & 40 & 42 & 40 & $0,000 * *$ \\
\hline Petani Inovator & 65 & 67 & 66 & $0,000 * *$ \\
\hline
\end{tabular}

Keterangan:

1. $0-50=$ Rendah, 51-75= Sedang, 76-100= Tinggi,

2. ** $\mathrm{p}<0,05$ (memiliki perbedaan nyata pada taraf $95 \%$ pada Uji $t$-Test) 
Sumber informasi yang tersedia dan sering tersedia adalah media konvensional. Petani sangat jarang melihat, mengamati dan membaca spanduk, leaflet, poster, majalah, koran walaupun tersedia di BPP di kecamatan ataupun di desa. Petani melihat sebagai bagian dari hiasan dari sebuah perkantoran walaupun spanduk atau poster tersebut sebenarnya memiliki makna informasi bagi petani. Petani sering dan senang menggunakan bahasa verbal dan langsung dari pada menggunakan bahasa tulisan. Hal ini berdampak pada petani, yaitu tidak menunjukkan pengaruh pada perilakunya dan tidak berbeda di dua kabupaten tersebut. Berbeda dengan media nonkonvensional petani masih menyimpan rasa penasaran dan menyimpan pertanyaan konfirmatif ke petani yang lebih tahu maupun ke penyuluh. Siaran pertanian sering ditayangkan setiap jumat dan sabtu oleh Televisi Republik Indonesia (TVRI) Provinsi Sumatera Selatan yang penanyangannya selalu melibatkan petani yang berhasil dan pakar dalam menjawab pertanyaan petani yang ada di Provinsi Sumatera Selatan. Berbeda dengan acara di Radio Republik Indonesia (RRI).

Hal ini dikarenakan waktu penyiaran yang tidak sesuai dengan waktu istirahat petani dan kurang membahas pertanyaan seputar masalah yang dialami petani. Unsur media nonkonvensional adalah internet dan penggunaan ponsel, alat ini digunakan oleh petani hanya bersifat alat komunikasi belum sepenuhnya sebagai alat pencarian dan penggalian informasi yang bersifat penyambung hubungan antara orang dan orang. Kelompok tani, lembaga inovasi dan petani inovator memiliki perbedaan yang berbeda di dua kabupaten perlakuannya oleh petani. Lembaga inovasi dan petani inovator dapat dijangkau oleh kelompok tani di Kabupaten Ogan Ilir, serta memiliki jarak yang dekat dengan Universitas Sriwijaya, Universias Muhammadiyah Palembang dan BPTP. Hal ini menunjukkan perbedaan di Kabupaten Banyuasin, petani di kabupaten ini jarang tersentuh secara langsung kegiatan inovasi dari kelembagaan pemerintah. Hal ini disebabkan oleh infrastruktur yang tidak menunjang baik sarana dan prasarana serta moda transportasi yang jarang.

Media non-konvensional, kelompok tani, lembaga inovasi dan petani inovator merupakan unsur yang membedakan di dua kabupaten. Hal ini ditunjang oleh sarana dan prasarana yang kurang merata pembangunannya antara Kabupaten Ogan Ilir dan Kabupaten Banyuasin. Malta et al. (2018) menyatakan bahwa Kabupaten Ogan Ilir mampu menerima sumber informasi secara leluasa, namun masih kurang keterpaannya terhadap pemberdayaan petani. Petani mampu memperoleh penjelasan dengan cepat dari beberapa sumber informasi, terutama pendampingan oleh penyuluh dan tokoh masyarakat serta kelembagaan ekonomi masyarakat setempat. Nurhayati et al. (2018) menyatakan bahwa pertemuan langsung tatap muka baik dengan dialog, ceramah, kunjungan petani ataupun petugas penyuluh mampu memberikan informasi awal buat petani termasuk penggunaan poster, pamflet dan siaran radio.

Hal ini dipengaruhi oleh karakteristik petani itu sendiri, sifat inovasi, keterjangkauan sarana produksi dan informasi serta dukungan keluarga dan mitra usaha yang mengelola usaha petani. Arus informasi melalui berbagai sumber mampu memberikan petani kemampuan dalam menggali dan mengkaji informasi secara akurat dan akuntabel. Gunawan et al. (2019), peran sumber informasi yang tepat dalam pertanian padi berkelanjutan tidak lepas dari dukungan penyuluhan yang terlihat dari materi penyuluhan dan intensitas penyuluh dalam menyuluh informasi tani kepada petani. Petani yang adaptif dalam bertani dinyatakan oleh Leeuwis (2009) adalah petani yang mampu mencari dan menggali informasi pengatahuan tani yang sesuai dengan kondisi lingkungan ekologis yang dimiliki petani sendiri. Petani mandiri adalah petani yang mampu mengembangkan dirinya dengan berbagai sumber informasi yang dimiliki dengan memanfaatkan kuantitas informasi secara langsung dan tidak langsung dengan melibatkan penyuluh sebagai transformator informasi yang bersumber dari kelompok tani, lembaga inovasi dan petani inovator yang memberikan informasi yang bermanfaat dan memiliki nilai ekonomi bagi petani sendiri.

\section{Dukungan Lingkungan Kelembagaan Pertanian}

Dukungan lingkungan kelembagaan pertanian merupakan dukungan yang mendorong dan membangun petani baik secara kelembagaan maupun kebijakan melalui berbagai program pembangunan pertanian. Dukungan lingkungan kelembagaan terdiri dari dukungan kebijakan, badan usaha milik desa (BumDes), dukungan perusahaan pertanian, dukungan penyuluhan, dukungan pemasaran, dukungan infrastruktur memiliki hubungan dan perbedaan di dua kabupaten tersebut. Kabupaten Ogan Ilir memiliki tingkat kunjungan penyuluh dan pemasaran produksi pertanian cukup baik, akan tetapi berbanding terbalik dengan Kabupeten Banyuasin. Hal ini disebabkan oleh: (1) fasilitas penyuluh 
yang terbatas; (2) jumlah penyuluh yang terbatas serta; (3) kondisi transportasi yang tidak memadai. Dukungan kebijakan di Kabupaten Ogan Ilir juga lebih baik, bila dibandingkan dengan Kabupaten Banyuasin. Hal ini disebabkan oleh Kabupaten Ogan Ilir lebih terbuka arus informasi dan merupakan penghubung antar wilayah kabupaten dengan Kota Palembang, sedangkan Kabupaten Banyuasin lebih terpencil dengan cakupan wilayah yang luas. Tingkat dukungan Rata-ratanya dapat dilihat pada Tabel 3.

Tabel 3. Rata-rata tingkat dukungan lingkungan kelembagaan pertanian di Kabupaten Ogan Ilir dan Kabupaten Banyuasin Provinsi Sumatera Selatan, 2019

\begin{tabular}{|c|c|c|c|c|}
\hline \multirow[b]{2}{*}{$\begin{array}{l}\text { Tingkat Dukungan } \\
\text { Lingkungan } \\
\text { Kelembagaan }\end{array}$} & \multicolumn{3}{|c|}{ Rata-rata } & \multirow[b]{2}{*}{$\begin{array}{c}\text { Uji Beda (t-Test) } \\
\text { Singnifikan (2-Tailed }) \\
\mathbf{p}<0,05\end{array}$} \\
\hline & $\begin{array}{l}\text { Kab. Banyuasin } \\
n=219\end{array}$ & $\begin{array}{c}\underset{n=75}{\text { Kab. Ogan Ilir }} \\
n=75\end{array}$ & $\begin{array}{c}\text { Total } \\
\mathrm{n}=\mathbf{2 9 4}\end{array}$ & \\
\hline Dukungan Kebijakan & 39 & 39 & 39 & $0,016 * *$ \\
\hline BUMDES & 16 & 22 & 18 & $0,000 * *$ \\
\hline $\begin{array}{l}\text { Dukungan Perusahaan } \\
\text { Pertanian }\end{array}$ & 34 & 33 & 34 & $0,005^{* *} *$ \\
\hline Dukungan Penyuluhan & 49 & 58 & 51 & $0,000 * *$ \\
\hline Dukungan Pemasaran & 56 & 56 & 56 & $0,013 * *$ \\
\hline Dukungan Infrastruktur & 43 & 44 & 43 & $0,000 * *$ \\
\hline
\end{tabular}

Keterangan:

1. $0-50=$ Rendah, $51-75=$ Sedang, $76-100=$ Tinggi,

2. ** $\mathrm{p}<0,05$ (memiliki perbedaan nyata pada taraf $95 \%$ pada Uji $t$-Test)

Managanta et al. (2018) menilai peran kelembagaan pertanian sangat diperlukan dalam mengusahakan pertanian yang dikelola. Dukungan tidak hanya bersifat bantuan, namun juga dalam bentuk sistem yang terlembaga dalam membantu dan menemukan solusi terhadap kendala masalah yang dihadapi petani. Yunita et al. (2012) menemukan bahwa lemahnya ketahanan petani disebabkan oleh dukungan lembaga yang kurang berperan dalam kehidupan sistem masyarakat. Hal ini didukung oleh Malta et al. (2018) yang menunjukkan bahwa kemampuan petani yang rendah ditambah dengan kurang memihaknya dukungan lembaga utamanya infrastruktur dan penyuluh yang kurang memadai. Dukungan lingkungan kelembagaan dari setiap sistem, baik kebijakan, badan usaha milik desa, perusahaan pertanian, penyuluhan, maupun pemasaran dan infrastruktur menjadi nilai penting dalam menciptakan pertanian yang maju. Kumar et al. (2017) Besarnya peranan kelembagaan pertanian dinilai cukup kuat membantu petani dalam pengelolaan usahatani yang dikelola petani langsung khususnya berupa modal produksi.

Sehingga adanya peran pemerintah dalam menjembatani antar lembaga petani menjadi bagian yang mampu memutus mata rantai pengelolaan pertanian yang menurunkan nilai tukar petani. Hal ini diperkuat oleh Gunawan et al. (2019) bahwa dukungan kelembagaan baik berupa pasar, kebijakan pemerintah terhadap petani, informasi berupa permodalan membantu petani dengan mendorong usaha pertanian agar mampu tetap pada pengembangan pertanian yang berkelanjutan. Indraningsih (2011) memperkuat bahwa peran penyuluh memiliki andil yang besar dalam regulator pembangunan pertanian di lapangan sehingga penyuluh dikenal sebagai ujung tombak pertanian. Lemahnya peran penyuluh berdampak pada kebijakan dan pelambatan lembaga pertanian yang menunjang pertanian. Oleh karena itu, keberadaan penyuluh dalam melaksanakan peran pendampingan, informasi dan edukator secara konsisten mampu menggerakkan dan mendorong petani dalam pembangunan pertanian yang mandiri.

Peran dukungan kebijakan, Bumdes, perusahaan pertanian, dukungan penyuluhan, dukungan pemasaran dan infrastruktur di dua kabupaten memiliki perbedaan yang signifikan. Hanya pada dukungan penyuluhan dan dukungan pemasaran terkategori sedang. Terdapat temuan yang sama pada hasil penelitian Sunartomo (2016) dan Gunawan et al. (2019) bahwa dukungan penyuluhan memiliki arti terhadap keberlanjutan usahatani petani padi sehingga dengan meningkatkan kualitas penyuluh 
secara langsung dan tidak langsung mampu memberikan dorongan kepada petani dalam mengelola usahatani secara berkelanjutan. Sedangkan, dukungan kebijakan, Bumdes, perusahaan pertanian dan infrastruktur yang lemah di Kabupaten Banyuasin dan Kabupaten Ogan Ilir. Hal ini berdampak pada rendahnya nilai pendapatan yang diterima petani. Oleh karena itu, dukungan pemerintah, perguruan tinggi, lembaga inovasi, penyuluh swasta serta petani inovator dapat meningkatkan pendapatan petani dengan meningkatkan kualitas produksi gabah dan beras yang dihasilkan petani. Berbeda dengan temuan Wetik et al. (2018) menemukan bahwa dukungan kelembagaan yang berpengaruh adalah dukungan penyuluh, dukungan mitra bisnis, serta permintaan sedangkan akses pasar dan akses permodalan tidak mempengaruhi petani dalam mengelola usahatani padi.

\section{Kemandirian Petani}

Kemandirian petani di Kabupaten Ogan Ilir dan Kabupaten Banyuasin terkategori sedang dan memiliki pengaruh yang nyata pada aspek daya saring dan sanding. Kemandirian petani yang sedang menunjukkan bahwa petani memiliki kemampuan dalam hal membudidayakan pertanian padi dimulai dari pengelolaan lahan yang suboptimal, pemilihan varietas yang baik dan unggul sesuai dengan kondisi lahan rawa, penanaman sesuai dengan kondisi iklim, pengendalian hama dan penyakit tanaman padi serta pengelolaan panen dan pascapanen yang menggunakan mekanisasi pertanian. Kemampuan daya saring dan daya sanding petani memberikan dampak terhadap perilaku bertani dalam menggunakan alat mekanisasi pertanian saat pengelolaan lahan dan pemanenan serta perilaku dalam melakukan penyimpanan dan perlakuan setelah panen. Perilaku tersebut mempengaruhi kualitas gabah yang dihasilkan oleh petani. Kemampuan perilaku bertani padi rawa sangat menentukan kualitas hasil produksi padi. Kemampuan daya saring petani ditunjukkan oleh adopsi petani dalam pengelolaan lahan pertanian dan pemanenan. Kemampuan daya sanding berdampak pada tingkat serapan produksi yang diterima oleh pedagang atau pembeli gabah di tingkat penggilingan dan pasar. Hal ini menunjukkan petani secara mandiri dengan dukungan fasilitas yang ada berjuang menciptakan nilai jual hasil tani yang lebih baik. Kemampuan daya saing, daya saring dan daya sanding petani di Kabupaten Banyuasin lebih baik dibandingkan Kabupaten Ogan Ilir. Hal ini disebabkan motivasi dan dorongan petani di Kabupaten Banyuasin yang lebih menantang dengan luasnya lahan garapan, dukungan permodalan yang didapat serta optimisme dengan harga jual yang menguntungkan petani. Selain itu, dukungan pemasaran tersedia dengan cepat diperoleh dengan harga di atas biaya pokok produksi. Dahulu Kabupaten Banyuasin dimanfaatkan sebagai tanaman kelapa sebagai komoditas kopra, selain tanaman pangan dan jagung, karena petani memiliki lahan yang luas. Seiring waktu nilai tanaman pangan meningkat sebagai bentuk ketahanan pangan serta nilai jual yang mampu mengembangkan tanaman padi lebih bernilai.

Malta et al. (2018) menyatakan bahwa kelemahan dari tingkat kemandirian petani disebabkan oleh kurangnya kemampuan petani untuk berkelompok. Hal ini disebabkan oleh: (1) petani merasa belum memiliki cukup bukti untuk lebih baik untuk berkelompok; (2) petani tidak merasa nyaman dalam kelompok karena kurang pembinaan serta; (3) kelompok masih dianggap pemecah belah kerukunan antar mereka. Petani di Kabupaten Banyuasin lebih mengandalkan jaringan yang telah ada yang mampu membeli produk mereka dengan cepat, sedangkan di Kabupaten Ogan Ilir, petani akan menjual gabah mereka saat harga baik. Hal lain adalah luas lahan garapan pertanian Kabupaten Ogan Ilir masih terbatas setahun sekali karena kondisi alam yang tidak menentu. Rata-rata tingkat kemandirian petani tersaji pada Tabel 4. 
Tabel 4. Rata-rata tingkat kemandirian petani di di Kabupaten Ogan Ilir dan Kabupaten Banyuasin, Provinsi Sumatera Selatan, 2019

\begin{tabular}{|c|c|c|c|c|}
\hline \multirow[b]{2}{*}{$\begin{array}{c}\text { Tingkat } \\
\text { Kemandirian } \\
\text { Petani }\end{array}$} & \multicolumn{3}{|c|}{ Rata-rata } & \multirow[b]{2}{*}{$\begin{array}{c}\text { Uji Beda (t-Test) } \\
\text { Singnifikan (2-Tailed) } \\
\text { p }<0,05\end{array}$} \\
\hline & $\begin{array}{c}\text { Kab. Banyuasin } \\
\mathbf{n}=219\end{array}$ & $\begin{array}{c}\text { Kab. Ogan Ilir } \\
n=75\end{array}$ & $\begin{array}{c}\text { Total } \\
\mathrm{n}=294\end{array}$ & \\
\hline Daya Saing & 65 & 50 & 67 & 0,559 \\
\hline Daya Saring & 74 & 58 & 65 & $0,000 * *$ \\
\hline Daya Sanding & 67 & 52 & 66 & $0,004 * *$ \\
\hline
\end{tabular}

Keterangan:

1. $0-50=$ Rendah, $51-75=$ Sedang, $76-100=$ Tinggi,

2. ** $\mathrm{p}<0,05$ (memiliki perbedaan nyata pada taraf $95 \%$ pada Uji $t$-Test)

Rangkuti (2009) dan Cai et al. (2008) melihat bahwa kemampuan petani perlu diberdayakan oleh lembaga pemberdayaan petani baik dalam bentuk lembaga modal dan lembaga pemberdayaan, pendidikan dan pelatihan petani. Hal ini dilakukan agar mampu meningkatkan kemampuan petani, meningkatkan kapasitas petani hingga mampu memiliki produksi yang baik dan harga yang mensejahterakan petani. Sadono et al. (2014) menyatakan bahwa dukungan kemandirian petani perlu diperhatikan aspek kelembagaan dan informasi pertanian. Peran kelompok yang lemah dalam bekerjasama berdampak pada lemahnya kemampuan petani dalam menghitung nilai risiko yang diterimanya serta keberlanjutan usahatani menjadi rentan dan gagal. Kemandirian petani mampu ditingkatkan di dua kabupaten dengan mengaktifkan fungsi kelompok serta membangun jaringan agribisnis dengan mengaktifkan kelembagaan permodalan, pendidikan dan penyuluhan, pemasaran dan nilai harga produk yang menguntungkan petani. Ruhimat (2015) menyatakan bahwa unsur kemandirian petani tidak terlepas dari motivasi petani, mengembangkan usahatani yang dikelola dengan menekankan pada karakteristik petani, dukungan pihak luar, peran penyuluh serta kelompok tani. Oleh karena itu, diperlukan langkah yang dapat meningkatkan kemandirian petani dimana meningkatkan kapasitas petani melalui pendidikan, pelatihan dan penyuluhan guna menguatkan persepsi petani terhadap informasi pertanian yang baik.

\section{Pengaruh Sumber informasi dan Dukungan Lingkungan Kelembagaan terhadap Kemandirian Petani}

Hipotesis yang dibangun dalam artikel ini adalah terdapat pengaruh sumber informasi pertanian dan dukungan lingkungan kelembagaan terhadap kemandirian petani. Hal ini memperkuat konsep Leeuwis (2009) bahwa sumber informasi dan dukungan kelembagaan memberikan peran kuat dalam meningkatkan kemampuan perilaku petani. Sumardjo (2020) menjelaskan bahwa kemandirian petani dibentuk oleh adapatasi dan antisipatif, daya saring petani dari masa ke masa, daya saing dan daya sanding petani. Dukungan lingkungan kelembagaan pertanian dan sumber informasi merupakan bagian dari syarat pokok dan pelancar pembangunan pertanian khususnya tanaman pangan. Peneliti menggunakan Program SmartPLS 3.2.9 untuk menjawab hipotesis ini. Tahapan awal penggunaan program tersebut adalah mencari nilai AVE harus lebih besar dari 0,50 serta melihat nilai loading factor besar dari 0,50 dan nilai $t$-value dengan taraf 5\% harus lebih besar dari 1,96. Hasil pengujian yang ada di dapat gambar model estimasi pengaruh sumber informasi dan dukungan lingkungan terhadap kemandirian petani dengan nilai AVE untuk sumber informasi dan dukungan lingkungan kelembagaan masih dibawah 0,50 sedangkan kemandirian petani telah cukup syarat sehingga tidak harus tereliminasi. Hal ini digambarkan pada Gambar 2. 


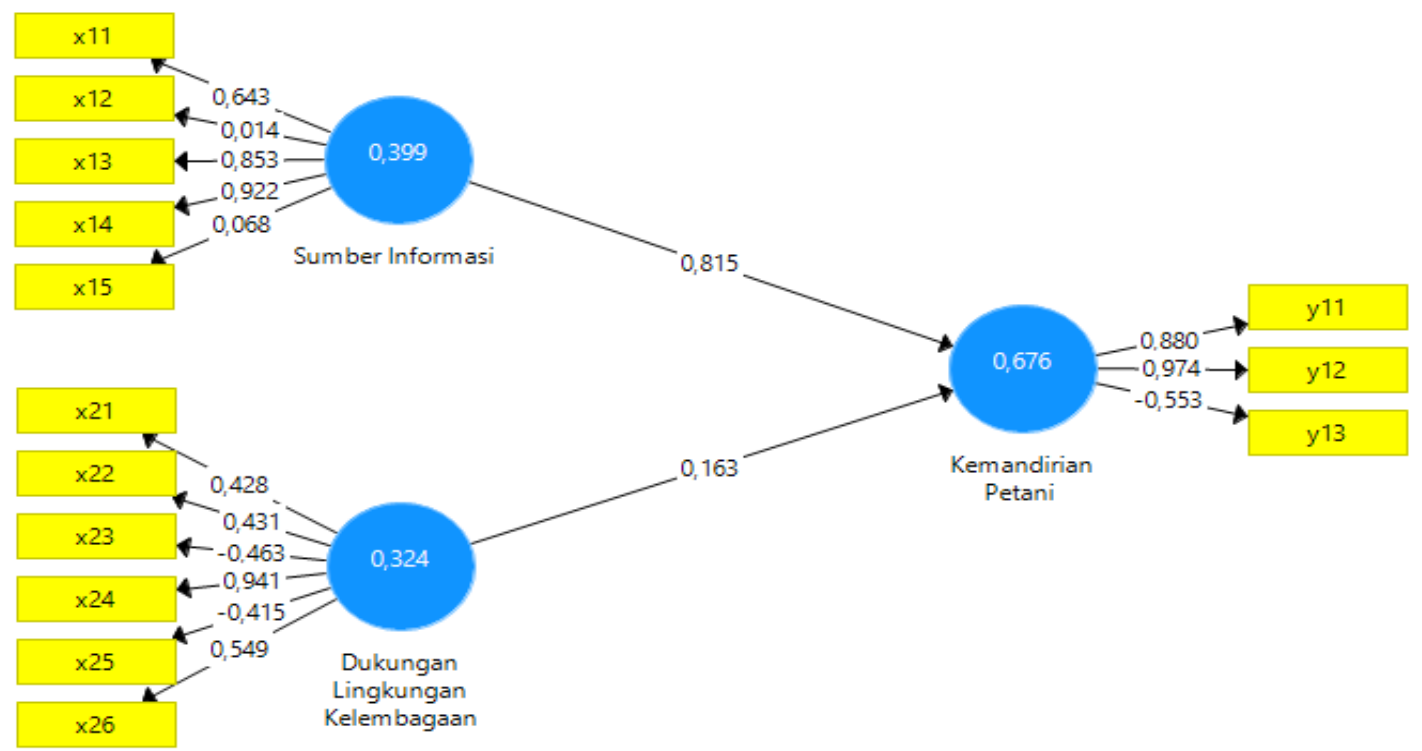

Gambar 2. Model estimasi awal pengaruh sumber informasi dan dukungan lingkungan.

Gambar 3 merupakan model estimasi akhir yang telah memiliki nilai AVE yang sesuai dengan syarat pengujian diatas 0,50. Akan tetapi, beberapa peubah manifest dari peubah sumber informasi satu dihilangkan X15 (petani inovator) karena nilai loading factor dibawah 0,5 dan t-value < 1,96, sedangkan pada dukungan lingkungan kelembagaan hanya dua yang mampu dipertahankan dengan pilihan model X21 (dukungan kebijakan) dan X24 (dukungan penyuluhan) dan X26 (dukungan infrastruktur) dimana masing-masing model tersebut memiliki nilai AVE $>0,50$. Merujuk pada teori dan temuan yang lebih memungkinkan adalah model dukungan lingkungan kelembagaan dengan dukungan kebijakan (X21) dan dukungan penyuluhan (X24), sedangkan X22 (Bumdes), X23 (perusahaan pertanian), X25 (dukungan pemasaran) dan X26 (dukungan infrastruktur) tidak cukup memenuhi standar nilai dari loading factor sebagai pengujian validitas dan reabilitas dari program. Hasil olahan tersebut ditampilkan pada Gambar 3.

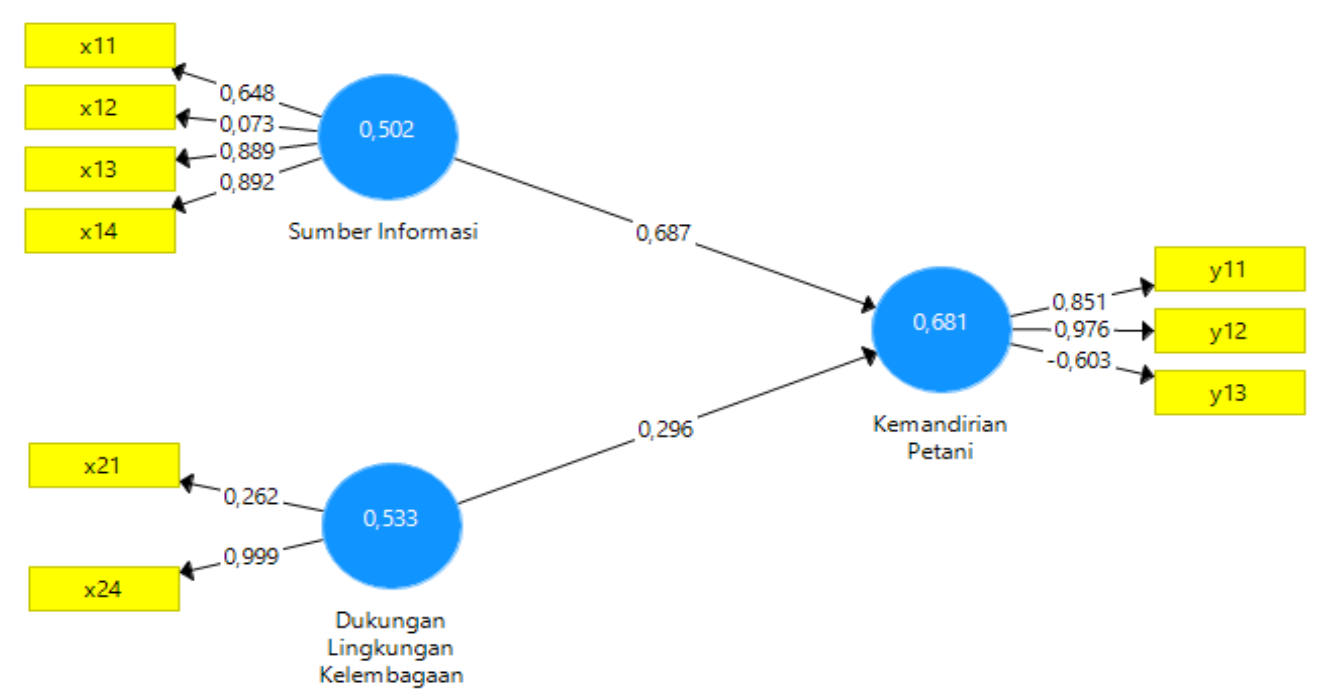

Gambar 3. Model estimasi akhir pengaruh sumber informasi dan dukungan lingkungan kelembagaan terdap kemandirian petani dengan nilai AVE.

Persamaan yang terbentuk adalah tingkat kemandirian petani $=0,687 *$ Sumber informasi $+0,296^{*}$ Dukungan lingkungan kelembagaan $+0,087, \mathrm{R}^{2}$ adalah 0,913 . Hasil persamaan ini membentuk pengaruh antara sumber informasi pertanian dan dukungan lingkungan kelembagaan sebesar 91,3\% 
dengan nilai pengaruh yang signifikan antar peubah laten eksogen dan peubah endogen. Peubah eksogen dari manifes sumber informasi yaitu akses media konvensional yang tidak memiliki nilai signifikan terhadap sumber informasi pertanian, sedangkan peubah manifestasi lainnya memiliki pengaruh yang signifikan dan bernilai postif. Nilai $\lambda$ dari peubah manifestasi dari sumber informasi yaitu media nonkonvensional $(\lambda 0,648)$, media konvensional $(\lambda 0,073)$, kelompok tani $(\lambda 0,889)$, lembaga inovasi $(\lambda 0,892)$. Nilai dari peubah dukungan lingkungan kelembagaan terdiri dari dukungan kebijakan $(\lambda 0,262)$ dan dukungan penyuluh $(\lambda 0,999)$, sedangkan nilai peubah endogen kemandirian petani adalah terdiri dari peubah manifes yaitu daya saing $(\lambda 0,851)$, daya saring $(\lambda 0,976)$ dan daya sanding $(\lambda-0,603)$. Model persamaan tingkat kemandirian petani disajikan dalam Gambar 4 .

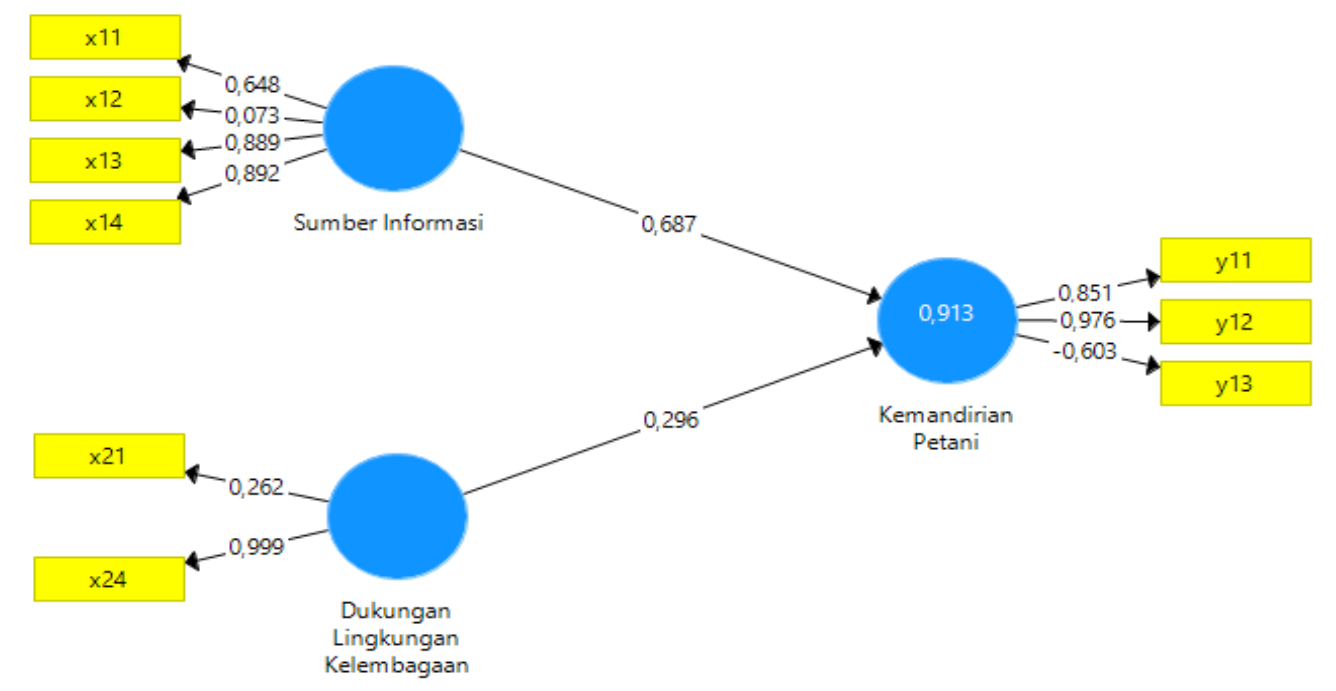

Gambar 4. Model pengaruh sumber informasi dan dukungan lingkungan kelembagaan terhadap kemandirian petani.

Penjelasan terhadap model menunjukkan nilai $\mathrm{f}^{2}$ pada dukungan lingkungan kelembagaan 0,252 dan pada sumber informasi 1,357 yang berarti nilai tersebut moderat pada peubah laten sumber informasi sedangkan pada dukungan lingkungan terkategori kuat memiliki pengaruh, sedangkan $\mathrm{Q}^{2}$ berada di $0,617\left(\mathrm{Q}^{2}>0\right)$. Hal ini dapat dimaknai bahwa model ini telah mampu merepresentasikan model penelitian. Nilai Goodness of Fit (GoF) dari model tersebut 0,47 yang berarti model tersebut mampu menjelaskan peubah dari eksogen dan endogen.

Kemandirian petani yang terbentuk dikalangan petani dipengaruhi oleh faktor sumber informasi dan dukungan lingkungan kelembagaan yang terdapat di lingkungan petani. Faktor ini mampu meningkatkan kemampuan, kompetensi petani dan kapasitas petani sebagai bagian dari individu petani maupun kelompok tani. Hasil perkalian antara path coefisien dan nilai korelasi dari sumber informasi menunjukkan bahwa faktor sumber informasi mempengaruhi kemandirian $65 \%$ dan dukungan lingkungan kelembagaan 26\%, sehingga model kemandirian petani memilki nilai pengaruh secara simultan 91\% dengan 9\% dipengaruhi oleh faktor lain. Gultom et al. (2017) menjelaskan bahwa perilaku komunikasi petani di Provinsi Lampung sangat mempengaruhi perilaku budidaya yang dikelola hingga petani mampu mengembangkan usahatani sayur. Hal ini diperkuat oleh Prawiranegara et al. (2017) bahwa faktor informasi dari masing-masing lembaga dan dukungan lingkungan kelembagaan mampu meningkatkan kemandirian petani baik daya saing, daya saring, dan daya sanding. Berbeda dengan hasil penelitian Lundahl dan Sjöholm (2013) menyatakan bahwa kemandirian petani dapat ditingkatkan dengan mencari alternatif usaha selain bertani, hal ini dilatarbelakangi oleh dukungan pembangunan pertanian yang lemah sehingga menyebabkan akses pasar dan harga yang kurang dan rendah.

Sumber informasi nonkonvensional berupa internet, aplikasi mobile, radio, televisi, media sosial mampu memberikan informasi awal bagi petani hingga dikonfirmasi melalui media konvensional melalui pertemuan kelompok, brosur ataupun spanduk. Hasil konfirmasi selanjutnya diperkuat melalui kelompok tani sebagai agen penguat petani termasuk dukungan dari lembaga inovasi dari berbagai lembaga baik Balai Besar Padi, Balai Pengkajian Teknologi Pertanian (BPTP) di wilayah Provinsi Sumatera Selatan dan perguruan tinggi. Informasi perlu diperkuat yang berbasis kelembagaan dengan 
masif ke petani dengan memproduksi pesan yang bernilai tambah dan mampu menjawab pertanyaan dan permasalahan petani.

Pengaruh sumber informasi dan dukungan lingkungan kelembagaan pertanian memiliki dampak terhadap kemandirian. Indraningsih (2011) menyatakan bahwa perlunya strategi penyuluhan pertanian yang berkelanjutan dalam mengimplementasikan UU RI no 16/ 2006 tentang penyuluhan. Strategi tersebut dimulai dengan koordinasi antar penyuluh di BPTP dan BPP sehingga mampu mengembangkan informasi yang bermanfaat langsung pada petani. Pemerintah pusat dan daerah perlu melakukan sinergitas antar program sehingga tercipta pemberdayaan petani yang berkelanjutan dengan menempatkan petani sebagai partnerships. Swastika dan Indraningsih (2020) juga menyatakan bahwa kemandirian petani didukung oleh adanya fasilitas informasi berupa penyuluh dan kelembagaan dalam menunjang kapasitas petani dalam hal pendidikan dan pelatihan, pemodalan, kebijakan harga serta keterlibatan petani dalam usaha desa yang mampu mengembangkan pengelalaan usahatani yang berkelanjutan.

Implikasi yang dapat dilakukan oleh pemerintah daerah dalam mengembangkan petani padi rawa di Sumatera Selatan khususnya di Kabupaten Ogan Ilir adalah meningkatkan peran penyuluh pertanian dan bersinergi dengan pihak BumDes, Bulog, perusahaan di bidang pertanian yang menerima hasil produksi padi serta mengembangkan kelompok swadaya mandiri di kalangan petani. Khusus Kabupaten Banyuasin strategi yang digunakan adalah meningkatkan kuantitas penyuluh pertanian dan kerjasama kemitraan dengan pihak perusahaan pertanian dalam memanfaatkan lahan dan menciptakan usaha-usaha pertanian di setiap kecamatan yang mampu meningkatkan nilai tambah dari hasil pertanian padi. Implikasi tersebut di Kabupaten Banyuasin dan Kabupaten Ogan Ilir dapat terealisasi dengan komitmen pemerintah daerah baik provinsi dan kabupaten dalam meningkatkan kualitas dan kuantitas penyuluh pertanian.

\section{KESIMPULAN}

Lemahnya pemanfaatan sumber informasi yang dimanfaatkan petani mengakibatkan kemandirian petani menjadi lemah. Hal ini berdampak pada dukungan lingkungan kelembagaan yang kurang maksimal dalam peningkatan kemandirian petani. Pentingnya kelompok tani dan petani contoh/petani inovator dalam arus informasi pertanian menunjang kebutuhan informasi dari berbagai aspek baik media nonkonvensional, konvensional serta lembaga inovasi. Dukungan kelembagaan pertanian yang lemah memiliki dampak terhadap kemandirian petani. Sehingga diperlukan peran penyuluhan untuk menunjang kebutuhan informasi pertanian dengan meningkatkan dukungan kebijakan, pengembangan badan usaha milik desa, dukungan perusahaan pertanian/swasta, dukungan penyuluhan yang terkini, dukungan pemasaran dan dukungan infrastruktur desa dan pertanian.

Kemandirian petani efektif ditingkatkan dengan mengembangkan sumber informasi yang akurat, terbaru dan mendalam serta mengandung nilai yang bermanfaat bagi petani. Maknanya teknologi informasi komunikasi yang telah tersedia di daerah tersebut penting untuk dimanfaatkan, yaitu dengan menggandeng media dan provider agar mampu memberikan informasi serta didampingi oleh lembaga yang berperan di wilayah desa dan kabupaten setempat. Penguatan dan pengembangan kelompok tani yang didukung dengan pendidikan dan pelatihan bagi petani yang difasilitasi oleh penyuluh maupun lembaga penelitian baik dari perguruan tinggi dan Balai Penelitian Kementerian Pertanian ataupun pihak swasta. Oleh karena itu perlunya: (1) sinergisitas antar kelembagaan pemerintah pusat, pemerintah daerah, swasta serta kelembagaan pertanian yang menunjang usahatani padi; (2) perkembangan teknologi nonkonvensional berupa digitalisasi informasi berdampak pada arah informasi yang multi tahap dimana informasi yang dikembangkan perlu ditapis dengan meningkatkan peran penyuluh dalam menyaring informasi dan mensosialisasikan informasi kepada petani; (3) perlunya mengkaderisasi petani milenial dengan pendekatan penyuluhan personal dan kelembagaan penyuluh dalam membangun sistem informasi pertanian di pedesaan; (4) perlunya dukungan semua pihak baik kelembagaan pertanian dan masyarakat luas dalam membangun informasi yang sehat dan mensejahterakan petani secara langsung dengan menciptakan pasar digital kepada petani; (5) pemerintah pusat dan daerah perlu membangun infrastruktur yang mampu meningkatkan nilai tambah dan nilai jual hasil pertanian. 


\section{DAFTAR PUSTAKA}

Anantanyu S, Slamet M, dan Tjitropranoto P. 2009. "Faktor-faktor yang mempengaruhi efektivitas kelembagaan petani (Kasus di Provinsi Jawa Tengah)". Jurnal Penyuluhan, 5(1): 81-91.

Cai J, Ung L, Setboonsarng S, dan Leung P. 2008. "Rice contract farming in Cambodia: Empowering farmers to move beyond the contract toward independence, ADBI Discussion Paper, No. 109". Tokyo: Asian Development Bank Institute (ADBI).

Deressa TT, Hassan RM, Ringler C, Alemu T, dan Yesuf M. 2009. "Determinants of farmers' choice of adaptation methods to climate change in the Nile Basin of Ethiopia". Global Environmental, 19(2): 248-255.

Gultom DT, Sumardjo, Sarwoprasodjo S, dan Muljono P. 2017. "Strategi pemenuhan kebutuhan informasi pertanian melalui pemanfaatan cyber extension di Propinsi Lampung". Sosiohumaniora, 19 (1): $64-69$.

Gunawan, Hubeis AVS, Fatchiya A, Susanto D. 2019."Dukungan penyuluhan dan lingkungan eketrenal terhadap adopsi inovasi dan keberlanjutan usaha pertanian padi organik". Jurnal Sosial ekonomi dan Kebijakan Pertanian Agriekonomika, 8 (1): 70-80. http://doi.org/10.21107/agriekonomika.v8i1.4951.

Indraningsih, K. 2011. "Pengaruh penyuluhan terhadap keputusan petani dalam adopsi inovasi teknologi usahatani terpadu". Jurnal Agro Ekonomi, 29 (1), 1-24. doi:http://dx.doi.org/10.21082/jae.v29n1.2011.1-24

Kumar A, Mishra AK, Saroj S, Joshi PK. 2017. "Institutional versus non-institutional credit to agricultural households in India: Evidence on impact from a national farmers' survey". Economic Systems, 41 (3): 420-432. https://doi.org/10.1016/j.ecosys.2016.10.005.

Leeuwis, C. 2009. "Komunikasi untuk inovasi pedesaan, berpikir kembali tentang penyuluhan pertanian. Terjemahan Dari: Communication for Rural Innovation, Rethinking Agricultural Extension”. Yogyakarta (ID): Kanisius.

Lundahl M dan Sjöholm F. 2013. Improving the lot of the farmer: development challenges in TimorLeste during the second decade of independence. Asian Economic Papers, 12 (2): 71-96. https://doi.org/10.1162/ASEP_a_00211.

Malta, Sumardjo, Fatchiya A, dan Susanto D. 2018. "Keberdayaan Transmigran dalam Berusahatani di Kabupaten Banyuasin dan Ogan Ilir Provinsi Sumatera Selatan". Jurnal Penyuluhan, 14 (2): 257-270.

Managanta AA, Sumardjo, Sadono D, dan Tjitropranoto P. 2018. "Influencing factors the interdependence of cocoa farmers in Central Sulawesi Province, Indonesia". International Journal of Progressive Sciences and Technologies (IJPSAT), 8(1): 106 -113.

Managanta AA, Sumardjo, Sadono D, dan Tjitropranoto P. 2019. "Dukungan dan peran kelembagaan dalam meningkatkan kemandirian petani kakao di Provinsi Sulawesi Tengah". Jurnal Tanaman Industri dan Penyegar, 6 (2): 51- 60.

Marquart J, O'Keefe GJ, and Gunther AC. 1995. "Believing in biotech: farmer's perceptions of the credibility of BGH information sources". Science Communication, 16 (4): 388402. https://doi.org/10.1177/1075547095016004002

Mittal S, dan Mehar M. 2013. "Agricultural information networks, information needs and risk management strategies: a survey of farmers in indo-gangetic plains of India". Socioeconomics working paper 10. Mexico, DF: CIMMYT.

Nurhayati, Hubeis AVS, Saleh A, dan Ginting B. 2018. "Strategi komunikasi dalam diseminasi inovasi teknologi budidaya padi berbasis pemetaan pengguna di Kabupaten Sidrap Sulawesi Selatan”. Jurnal Penyuluhan, 14 (2): 324-334.

Prawiranegara D, Sumardjo, Lubis DP, dan Harijati S. 2016. "Pengaruh kualitas informasi berbasis cyber terhadap kapabilitas petani sayuran mengelola inovasi di Jawa Barat". Sosio humaniora, 18 (2): 177- 184. 
Rangkuti PA. 2009. "Strategi komunikasi membangun kemandirian pangan". Jurnal Litbang Pertanian, 28 (2): 39 - 45.

Ruhimat IS. 2015. "Tingkat motivasi petani dalam penerapan Sistem Agroforestry". Jurnal Penelitian Sosial dan Ekonomi Kehutanan, 12 (2): 1-11.

Sadono D, Sumardjo, Gani DS, dan Amanah S. 2014. "Farmer empowerment in the management of rice farming in two districts in West Java". Journal Rural Indonesia, 1 (1): 106 - 126.

Shahbaz B, Ali T, Khan IA, dan Ahmad M. 2010. "An analysis of the problems faced by farmers in the mountains of northwest Pakistan: Challenges for agri extension". Pakistan Journal of Agricultural Science, 47 (4): 417-420.

Suhaeti RN, Hubeis AV, Pranadji T, Sarma M, dan Saleh A. 2015. "Innovation communication of submergence tolerant rice variety and effect of farmers external factors on innovation diffusion”. International Journal of Reasearch in Agriculture and Food Sciences, 3 (3): 1 - 9.

Sumardjo. 2019. "Penyuluhan di era komunikasi digital dalam mewujudkan kesejahteaan masyarakat kelautan dan perikanan". Seminar nasional perikanan dan penyuluhan Sekolah Tinggi Perikanan Bogor. Bogor : STP Bogor.

Sumardjo. 2020. Tantangan dan peluang profesi penyuluhan dalam pembangunan nasional. Disampaikan dalam webinar tantangan dan peluang dalam pembangunan nasional, 08 Agustus 2020. Lampung (ID). Universitas Lampung.

Sunartomo, A. F. 2016. "Kapasitas Penyuluh Pertanian dalam Upaya Meningkatkan Produktivitas Pertanian di Jawa Timur". Agriekonomika, 5 (2): 125-136. DOI: http://dx.doi.org/10.21107/agriekonomika.v5i2.1343.

Swastika DKS, dan Indraningsih KS. 2020. "Strategy formulation of farmers capacity building through technological innovation in disadvantaged regions of Indonesia" Jurnal Agro Ekonomi, 38 (1):15-27 DOI: http://dx.doi.org/10.21082/jae.v38n1.2020.15-27

Van den Ban AW, dan Hawkins HS. 1999. "Penyuluhan Pertanian”. Yogyakarta (ID): Kasinus.

Wetik JD, Saleh A, Asngari PS, Lubis DP. 2018. The effect of internal factors, need information and external factors to entrepreneurial characteristics of rice farmers. International Journal of Social Science and Economic Research, 03 (06): 2519-2529.

Yunita, Sugihen BG, dan Asngari PS. 2012. "Strategi peningkatan kapasitas rumah tangga petani padi sawah lebak menuju ketahanan pangan rumah tangga (kasus di Kabupaten Ogan Ilir dan Ogan Komering Ilir, Sumatera Selatan)". Jurnal Penyuluhan 8 (1): 42 - 54. 